\title{
Donald Trump's Social Media Communication or the voice of a man is stronger than the voice of an institution
}

\author{
Assist. Prof. PhD. Tănase Tasențe \\ "Ovidius" University of Constanta, Romania \\ office@pluscommunication.eu \\ Prof. univ. dr. habil. Mihaela Rus \\ "Ovidius" University of Constanta, Romania \\ psiholog_m@yahoo.com
}

\begin{abstract}
Social Media (Facebook, Instagram, Twitter, etc.) have revolutionized the communication strategies of public institutions in recent years, and communication strategies have understood the different principles on which these new media have been built, compared to traditional means of communication. Beyond the huge openness of these social environments, Social Meda is encouraging users to participate in the in the government process and created a new mechanism through which institution becomes a person, and institutional communication becomes interpersonal communication. This was speculated by many candidates who have won such a high online reputation that their voice can be stronger than the voice of an institution. This study focused on analyzing the Social Media communication strategy of Donald Trump, from 1 July 2018 to 1 July 2019. Thus, we have analyzed the Key Performance Indicators (KPIs) that facilitate Social Media communication, we have identified and analyzed the messages that generate high engagement from users as well as the dominant reactions generated by the online audience.
\end{abstract}

Keywords. Donald Trump, US President, Social Media Communication, Web 2.0, online reactions, Facebook

\section{Introduction}

With the development of online social networks, a phenomenon called by experts as Web 2.0, the field of political communication has changed radically, the structure of political discourse has been rethought, including public opinion polling techniques and methods of analyzing public reaction.

Among the early politicians who used Social Media in the election campaign was Barack Obama in 2008 when he defeated his opponent, Hillary Clinton. Maria Magdalena Jianu (2009) remarks that "no channels like CNN or ABC have brought Obama the decisive advantage, but social networking sites such as Facebook, Myspace, forums, blogs, generally attended by students (the current US president had 320,000 online supporters, compared to the 5300, as Hillary Clinton had).

The year 2008 was considered by many specialists as the decline of television overthrow in political communication, being replaced by a new era - Social Media - that offered the opportunity of politicians to reach out to the public bypassed by all traditional media: young people.

In that electoral campaign, Barack Obama managed to mobilize young people to ask for their opinion on any issue of interest to society and interact with them in a way that no politician had ever done before. The success of his online campaign was due to the fact that his speech was adapted to the online environment, the formal style of the speech was replaced by a more colloquial one, and the young people resonated with this new approach and they have shared his electoral messages in all the social network nodes. That new approach has become such a phenomenon that so many people who 
have not been interested in politics until then have become frenetic supporters in the online environment of Barack Obama.

This trend has been adopted in the years to come by more and more countries in Europe, Germany being the first overseas country to adopt this means of communication in the electoral campaign and the German interest in the political debate on Facebook and Twitter "has increased significantly, 5-8 times in 2012 compared to 2010" (Stieglitz, Brockmann, Xuan, 2012). The first electoral campaigns analyzed in Romania are the 2008 parliamentary elections and the presidential elections in 2009. Among them, we recall a study titled "Social Media and Political Communication. Case Study Parliamentary Parties in Romania "(Tasente, Ciacu, 2013), which shows that the Romanian parliamentary parties use Social Media moderately, but do more to propagate the political message, and less to interact with online audience. The same study reveals that political parties that have had a great deal of support in the Social Media (both in terms of the number of fans and especially of the interaction) have been successful in the parliamentary elections, achieving an electoral score that allowed them to accede to government. Those parties understood the importance of Social Media in social interaction, and continued their social media communication campaigns after the elections.

During the 2016 U.S. Election, Saud Alashri et al. (2018) from Arizona State University analyzed 22,233 posts and 48,991,502 comments spanning the entire period since the first candidate announced their campaign (Jan 1st, 2015) until the time Donald J. Trump was assumed to be the winner of the 2016 election (end of the day, November 8th, 2016). They identified the characteristics of people who interacted with candidates during the 2016 U.S. elections on Facebook: (1) they identified policy related topics that bring political polarization within candidates' posts using topic modeling, (2) they proposed a novel approach to classifying participants based on the positive and negative sentiments expressed in their comments. Moreover, the study showed how a post by a candidate, especially the tone expressed in it (positive or negative) impacts the reponses of the various groups of commentators and how the sentiments spread around invididuals (candidates) and the topics (policy viewpoints and/or priorities). For the first time, the importance of the emotional reactions of the public and the way in which the online audience reacts more emotionally than rationally in political debates was analyzed.

\section{$2 \quad$ Social Media Strategies of President Donald Trump (01.07.2018 - 01.07.2019)}

\subsection{Research objectives}

O1: Analyze the Key Performance Indicators (KPIs) that facilitate Social Media Communication of Donald Trump, the President of United States of America

O2: Identify and analyze messages that generate high engagement from users

O3: Analyzing the dominant reactions generated by the online audience on Donald Trump's Facebook pages

O4: Analyze the timeframe where the audience is most active on Facebook.

\subsection{Methodology}

To achieve the research objectives, we will use both quantitative and qualitative methods. Thus, we will analyze the key performance indicators (KPIs) that facilitate Donald Trump's online communication, namely: the number of fans, the average weekly increase in the number of fans, the number of daily posts, the engagement rate, the dominant reactions, etc. The monitoring period is 01.07.2018 - 01.07.2018.

\subsection{Centralization and data analysis}




\begin{tabular}{|c|c|c|c|c|c|c|c|c|c|}
\hline Type & Date & Likes & Comm & Shares & Love & Haha & Wow & Sorry & Anger \\
\hline photo & $06.10 .2018^{1}$ & 479000 & 39153 & 132703 & 131543 & 1542 & 848 & 632 & 5740 \\
\hline status & $08.06 .2019^{2}$ & 421071 & 60731 & 100559 & 83409 & 3766 & 2562 & 57 & 257 \\
\hline photo & $17.01 .2019^{3}$ & 362441 & 64359 & 294617 & 135409 & 73818 & 2120 & 172 & 933 \\
\hline photo & $25.12 .2018^{4}$ & 345478 & 45420 & 41524 & 88038 & 2338 & 525 & 68 & 323 \\
\hline status & $24.03 .2019^{5}$ & 298686 & 27037 & 35319 & 68362 & 4392 & 372 & 40 & 230 \\
\hline status & $24.03 .2019^{6}$ & 281984 & 53406 & 12384 & 57056 & 5859 & 436 & 71 & 261 \\
\hline photo & $14.06 .2019^{7}$ & 271243 & 59547 & 23304 & 59882 & 2137 & 297 & 44 & 145 \\
\hline status & $21.06 .2019^{8}$ & 266560 & 36197 & 46807 & 41813 & 5791 & 1691 & 343 & 1278 \\
\hline status & $22.06 .2019^{9}$ & 249788 & 27247 & 15753 & 40559 & 6867 & 616 & 199 & 486 \\
\hline photo & $\begin{array}{l}06.01 .2019 \\
10\end{array}$ & 237093 & 31733 & 40615 & 51247 & 24644 & 1124 & 195 & 892 \\
\hline video & $\begin{array}{l}30.06 .2019 \\
11\end{array}$ & 217078 & 22233 & 46206 & 47274 & 2956 & 6003 & 58 & 291 \\
\hline status & $\begin{array}{l}09.01 .2019 \\
12\end{array}$ & 213793 & 60258 & 28355 & 35295 & 14732 & 1729 & 1633 & 3032 \\
\hline photo & $\begin{array}{l}26.04 .2019 \\
13\end{array}$ & 194681 & 46850 & 33558 & 48908 & 1097 & 287 & 23 & 65 \\
\hline status & $\begin{array}{l}24.03 .2019 \\
14\end{array}$ & 192299 & 17326 & 9724 & 42913 & 4605 & 323 & 82 & 206 \\
\hline status & $\begin{array}{l}13.06 .2019 \\
15\end{array}$ & 191306 & 35664 & 11543 & 37078 & 1535 & 1355 & 47911 & 113 \\
\hline
\end{tabular}

The Facebook page owned by US President Donald Trump has 24.2 million fans and a weekly average increase of $0.18 \%$. Also, specialists in communication of the President published daily on average 8.6 posts, the rate engagement to social media activity is $2.3 \%$. According to the analysis, Donald Trump exploits $31 \%$ of the full potential offered by his page at this time. The Facebook page has seen steady increases from July 1, 2018 to July 1, 2019, with the exception being between May and June 2019, when more than 170,000 users became fans.

\footnotetext{
${ }^{1}$ http://www.facebook.com/153080620724/posts/10161205279685725

${ }^{2} \mathrm{http}: / /$ www.facebook.com/153080620724/posts/10161208623455725

${ }^{3} \mathrm{http}: / /$ www.facebook.com/153080620724/posts/10161209422880725

${ }^{4} \mathrm{http} / / / \mathrm{www}$. facebook.com/153080620724/posts/10161208977535725

${ }^{5}$ http://www.facebook.com/153080620724/posts/10161210391640725

${ }^{6} \mathrm{http}: / /$ www.facebook.com/153080620724/posts/10161211097400725

${ }^{7} \mathrm{http}: / /$ www.facebook.com/153080620724/posts/10161212929945725

${ }^{8} \mathrm{http}: / /$ www.facebook.com/153080620724/posts/10161213732705725

${ }^{9} \mathrm{http}: / /$ www.facebook.com/153080620724/posts/10161213964305725

${ }^{10} \mathrm{http} / / / \mathrm{www}$. facebook.com/153080620724/posts/10161213696235725

${ }^{11} \mathrm{http}: / / \mathrm{www}$. facebook.com/153080620724/posts/10161214149490725

${ }^{12} \mathrm{http} / / / \mathrm{www}$. facebook.com/153080620724/posts/10161213720120725

${ }^{13} \mathrm{http} / / / \mathrm{www}$. facebook.com/153080620724/posts/10161216231670725

${ }^{14} \mathrm{http} / / / \mathrm{www}$. facebook.com/153080620724/posts/10161217497635725

${ }^{15} \mathrm{http} / / / \mathrm{www}$. facebook.com/153080620724/posts/10161214802140725
} 


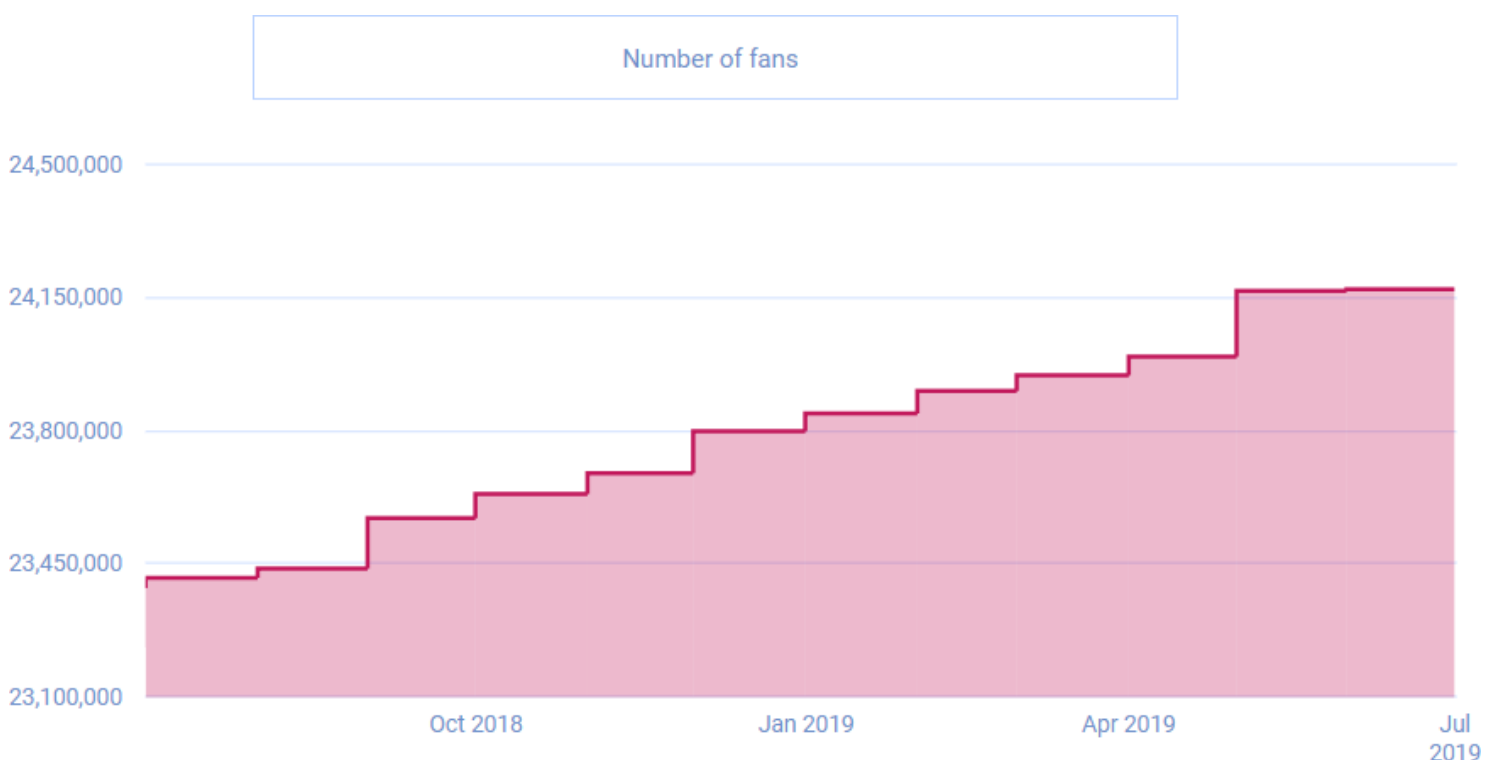

Figure 1 - Evolution of the number of fans of Donald Trump's Facebook page (1 July 2019 - 1 July 2019)

During the monitored period, July 1, 2018 - July 1, 2019, 1958 posts were published and videos were the most frequent $(37.9 \%)$, followed by photos $(25,8 \%)$, links $(19.9 \%)$, and statuses $(16.4 \%)$.

The most commonly used keywords that have generated a very good rate of interaction are: border, Great, Wall, Fake, Security, Immigration, winning, democrats, years, join, live, people, media, day, history. On the other hand, keywords that generated a lower rate of interaction were: economy, scheduled, meeting, sign, Donald, nation, job, American, States, Republicans, America, President, back, make, continue, support, works, secretary, travel etc.

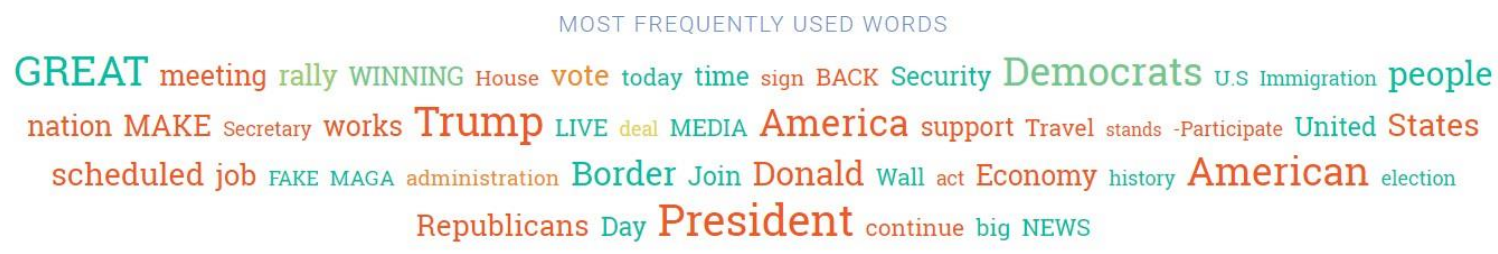

size $=$ frequency

green $=$ high engagement

red $=$ low engagement

\section{Which topics and phrases do appear most often?}

Figure 2 - Most frequently used words in posts

The indicator of the dominant reaction shows that the "love" reaction is the most common, followed by "sad", "sad", "haha" and "wow". At the opposite end, we find dominant reactions such as "like" (moderate, sometimes neutral) and angry. So, Donald Trump has succeeded, through his postings, to stir up strong and mobilizing reactions, which usually lead to the dissemination of information in other social groups and the build-up of a generalized emotion around the transmitter and the transmitted subject.

According to data analysis, Donald Trump concentrates its Social Media communication strategy on messages that have no emotional impact on the public, and they do not generate engagement. It is recommended that the communication strategy focuses on posts that predispose to love and sad 
reactions because they have a very high engagement rate. Thus, Donald Trump fans are more sensitive to a less formal message but are meant to excite and sensitize public opinion.

Most fans were active every day from 20:00 to 24:00 (New York time), but Donald Trump often posted during the day when most of the audience was not active on Facebook, which affected not only the reach indicator, but also especially the engagement indicator.

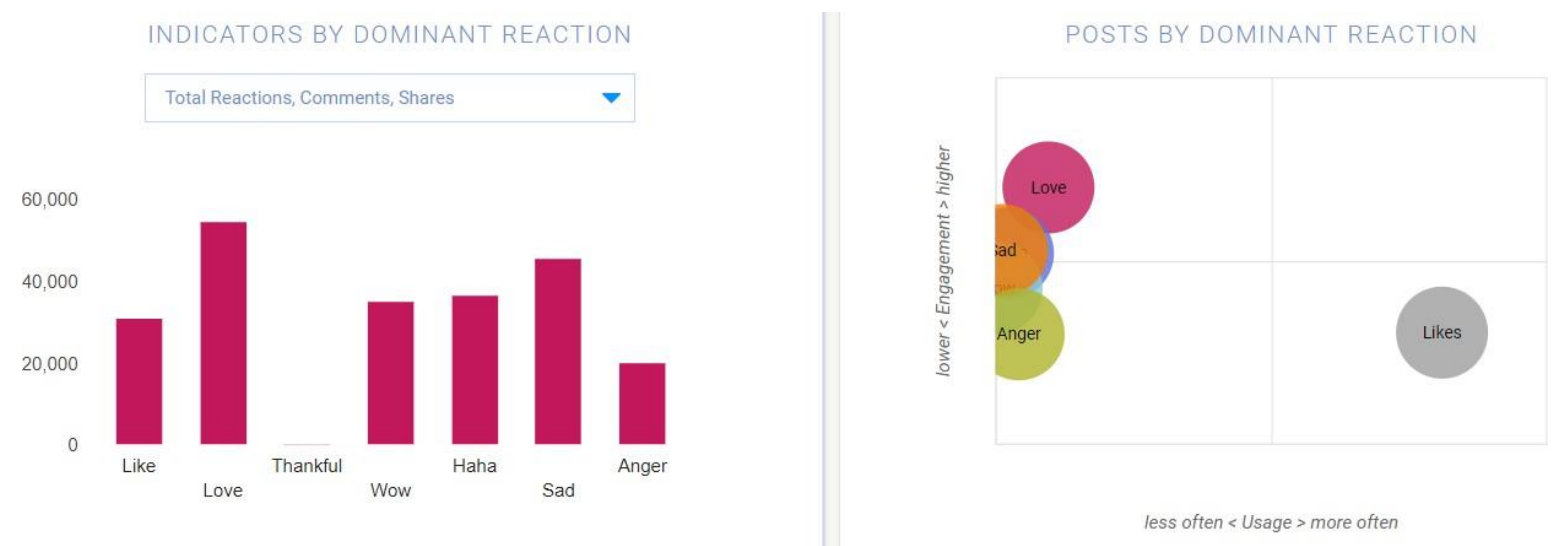

Figure 3 - Indicators by dominand reactions and posts by dominant reactions

Posts with the best engagement rate

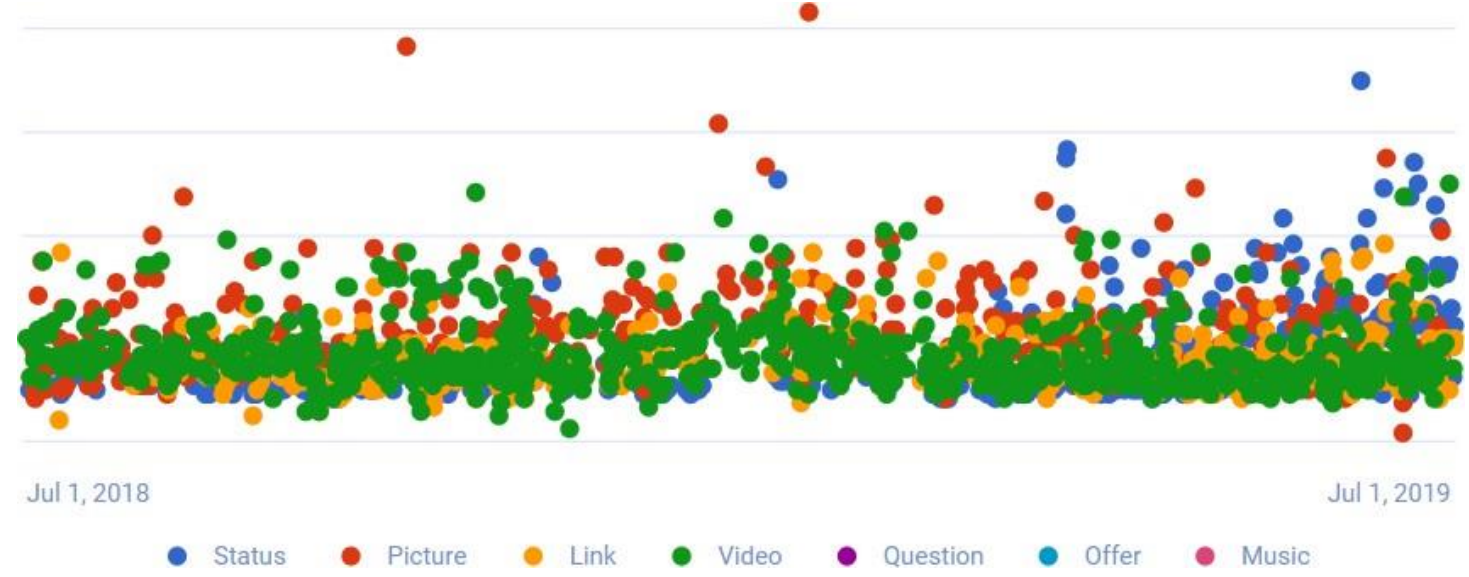

Figure 4 - Evolution of postings by category and impact

a. On January 17, 2019, Donald Trump publishes a letter to Nancy Patricia D'Alesandro Pelosi Speaker (President) of the House of Representatives and a member of the opposition party, with the following ironic message: "Due to the Shutdown, I am sorry to inform you that your trip to Brussels, Egypt, and Afghanistan has been postponed. We will reschedule this sevenday excursion when the Shutdown is over. In light of 800,000 great American workers not receiving pay, I am sure you would agree that postponing this public relations event is totally appropiate. I also feel that, during this period, it would be better if you were in Washington negotiating with me and joining the Strong Border Security movement to end the Shutdown. Obviously, if you would like to make your journey by flying commercial, that would certainly be your prerogative. I look forward to seeing you soon and even more forward to watching our 
open and dangerous Southern Bordern finally receive the attention, funding, and security it so desperately deserved!". The message was very well received by Donald Trump fans, the posting generating sympathetic reactions to the President and many supportive messages. Thus, out of total responses, 362,441 were likes, 135,409 love, 73,818 haha, 2120 wow, 172 sad, 933 angry, 64,359 comments and 294,617 shares.

Donald J. Trump

17 ianuarie -

Dear Madame Speaker.

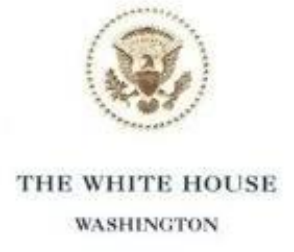

January 17,2019

The Honorable Nancy Pelosi

Speaker of the

House of Representatives

Washington, D.C. 20515

Dear Madame Speaker:

Due to the Shutdown, I am sorry to inform you that your trip to Brussels, Egypt, and Afghanistan has been postponed. We will reschedule this seven-day excursion when the Shutdown is over. In light of the 800,000 great American workers not receiving pay, I am sure you would agree that postponing this public relations event is totally appropriate. I also feel that, during this period, it would be better if you were in Washington negotiating with me and joining the Strong Border Security movement to end the Shutdown. Obviously, if you would like to make your journey by flying commercial, that would certainly be your prerogative.

I look forward to seeing you soon and even more forward to watching our open and dangerous Southern Border finally receive the attention, funding, and security it so desperately deserves!

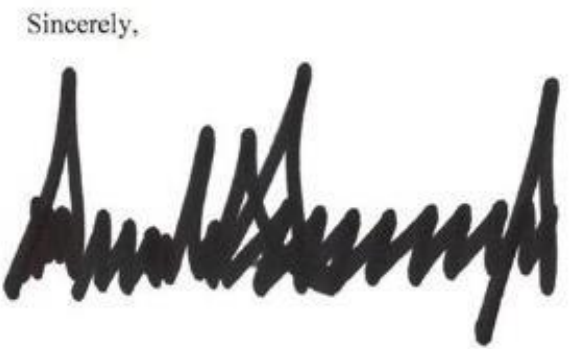

Figure 5 - The post with the highest engagement rate (July 1, 2018 to July 1, 2019)

b. On October 6, 2018, Donald Trump congratulates the US Senate to confirm the nomination from Republicans, Judge Brett Kavanaugh, to the United States Supreme Court. Also, in the same message, President Trump says he is very excited, and on the same day he will sign his Commission of Appointment. Post generated strongly positive reactions to the President Trump, as follows: 479,000 likes, love 131 543, 39153 comments and 132703 shares. The haha, sad and angry reactions are insignificant in number. 
c. In another post on June 8, 2019, Donald Trump reports that the United States of America has reached a signed agreement with Mexico. "The Tariffs scheduled to be implemented by the U.S. on Monday, against Mexico, are hereby indefinitely suspended. Mexico, in turn, has agreed to take strong measures to stem the tide of Migration through Mexico, and to our Southern Border. This is being done to greatly reduce, or eliminate, Illegal Immigration coming from Mexico and into the United States. Details of the agreement will be released shortly by the State Department. Thank you!". Also posting generated strongly positive reactions, mostly likes (421.071) reactions of "love" (83.409), comments (60 731) and shares (100 559).

d. On December 25, 2018, Donald Trump sends Merry Christmas on his behalf and First Lady Melania Trump along with a congratulatory photo in which the two are present. The post generated "like" reactions $(345,478)$, love $(88,038)$, comments $(45,420)$ and shares $(41,524)$.

e. The post on March 24, 2019 is only formed by a text message without other multimedia elements. The message is: "No Collusion, No Obstruction, Complete and Total Exoneration. KEEP AMERICA GREAT!". The post received many likes $(298,686)$, love $(68,362)$, haha (4392), comments $(27,037)$ and shares $(35,319)$.

f. On June 21, 2019, Donald Trump criticized former President Barack Obama, who made "a desperate and terrible deal with Iran - Gave them 150 Billion Dollars plus 1.8 Billion Dollars in CASH!" In the same post, Donald Trump continues: "Iran was in big trouble and he bailed them out. Gave them a free path to Nuclear Weapons, and SOON. Instead of saying thank you, Iran yelled Death to America. I terminated deal, which was not even ratified by Congress, and imposed strong sanctions. They are a much weakened nation today than at the beginning of my Presidency, when they were causing major problems throughout the Middle East. Now they are Bust! On Monday they shot down an unmanned drone flying in International Waters. We were cocked \& loaded to retaliate last night on 3 different sights when I asked, how many will die. 150 people, sir, was the answer from a General. 10 minutes before the strike I stopped it, not proportionate to shooting down an unmanned drone. I am in no hurry, our Military is rebuilt, new, and ready to go, by far the best in the world. Sanctions are biting \& more added last night. Iran can NEVER have Nuclear Weapons, not against the USA, and not against the WORLD!". The posting also generated negative feedback from Barack Obama's supporters, but Donald Trump's supporters are numerically major, so negative messages were immediately covered by a positive message series. In terms of responses, posting generated 266,560 likes, 41,813 love, 5791 haha, 1691 wow, 343 sad, 1278 angry, 36,197 comments and 46,807 shares.

\section{$3 \quad$ Conclusions}

In the analyzed period, July 1, 2018 - July 1, 2019, Donald Trump used key messages that generated various reactions: from like, love, wow to sad, anger and haha. However, the posts that have generated love and sad reactions have had the highest engagement from the audience, but Donald Trump has rarely used such key messages to starve more of the fans' emotions (posts that generate love and sad reactions become viral much easier).

The posts with the highest engagement rate were of three types: (1) ironies against opposition politicians (a) the irony about Nancy Pelosi being on a PR trip to Brussels, Egypt and Afghanistan, while 800,000 Americans are not paid or b) Barack Obama is accused by Donald Trump of that he made "a desperate and terrible deal with Iran - Gave them 150 Billion Dollars plus 1.8 Billion Dollars in cash"), (2) praising his Administration policy, (3) holiday wishes (eg Christmas, Thanks Giving, 4th of July, etc.).

However, Donald Trump does not use all the resources that its Facebook page can provide. For example, only $0.27 \%$ of the 24.2 million fans interact with posts, and $2.3 \%$ is the engagement rate. For the most part, this does not happen because of the topics chosen in the posts, but mainly because of the hours and days when messages are posted. Also, we have noticed that the most fans were active every 
Vol. 1, 2019

day from 20:00 to 24:00 (New York time), but Donald Trump often posted during the day when most of the audience was not active on Facebook, which affected not only the reach indicator, but also especially the engagement indicator.

\section{$4 \quad$ References}

[1] Jianu, M. M. (2009). "Aspecte ale comunicării politice actuale”, Analele Universităţii "Constantin Brâncuşi” din Târgu Jiu. Târgu-Jiu: Seria Litere şi Ştiinţe Sociale (3), 27.

[2] Stieglitz, S., Brockmann, T. Xuan, L.D. (2012). "Usage of Social Media for Political Communication", PACIS 12 Proceedings

[3] Tasente, T., Ciacu, N. (2013). "Social Media and Political Communication. Case Study - The Parliamentary Parties in Romania". Sfera Politicii, Vol XXI, nr. 2 (174), 147-160.

[4] Alashri, S., Parriott, E., Kandala, S. S., Aqazu, Y., Bajaj, V., Desouza, K.C. (2018), "The 2016 US [5] Presidential Election on Facebook: An Exploratory Analysis of Sentiments". Proceedings of the 51 st Hawaii International Conference on System Sciences 